\title{
ESTIMATING THE EFFECT OF THE COVID-19 OUTBREAK EVENTS ON THE INDONESIA SECTORAL STOCK RETURN
}

\author{
Salsa Dilla ${ }^{* 1}$, Linda Karlina Sari*), and Noer Azam Achsani*) \\ *) School of Business, IPB University \\ Jl. Pajajaran, Bogor 16151, Indonesia
}

\begin{abstract}
COVID-19 has become a global issue that bought a simultaneous effect all over the world. This outbreak has caused a significant impact on the economic stability including the stock market performance. This research used event study methodology to evaluate the Indonesia's sectoral stock market performance which is represented by companies with the biggest market capitalization in Indonesia. Estimating the COVID-19 outbreak events, the sample of the study consisted of daily sectoral indices stock data from 1 December 2017 to 14 April 2020. The market model is used to predict expected stock returns and simple regression to get the parameters of the equation. By using a t-test, it can be concluded whether the virus outbreak caused an abnormal return on the sectoral indices. The finding showed that the abnormal returns were found in the Basic Industry and Chemicals sector, Infrastructure, Utilities and Transportation sector, Agricultural sector and Mining sector. Furthermore, Basic Industry and Chemical sector, which is represented by Barito Pasific Ltd., give the greatest reaction to the stock market performance in Indonesia due to COVID-19.
\end{abstract}

Keywords: abnormal return, event study, stock return, COVID-19, Indonesia

\begin{abstract}
Abstrak: COVID-19 telah menjadi isu global yang memberikan efek simultan ke seluruh dunia. Wabah ini menyebabkan dampak yang signifikan pada stabilitas perekonomian yang tentunya juga mempengaruhi kinerja pasar saham. Penelitian ini menggunakan pendekatan event study untuk mengevaluasi kinerja pasar saham sektoral Indonesia yang diwakili oleh perusahaan-perusahaan dengan kapitalisasi pasar terbesar di Indonesia. Dengan mengestimasi dampak COVID-19, sampel penelitian terdiri atas data indeks saham sektoral harian dari 1 Desember 2017 hingga 14 April 2020. Market model digunakan untuk memprediksi expected stock returns dan penggunaan regresi sederhana untuk memperoleh parameter persamaan. Melalui uji t kemudian dapat disimpulkan apakah wabah COVID-19 menyebabkan abnormal return dalam indeks saham sektoral. Hasil penelitian menunjukkan bahwa abnormal returns ditemukan pada sektor Industri Dasar dan Kimia, sektor Infrastruktrur, Utilitas dan Transportasi, sektor Pertanian, dan sektor Pertambangan. Lebih lanjut, sektor Industri Dasar dan Kimia yang diwakili oleh PT Barito Pasific Tbk. memberikan respon terbesar terhadap pasar saham di Indonesia sebagai dampak dari COVID-19.
\end{abstract}

Kata kunci: abnormal return, event study, return saham, COVID-19, Indonesia

\footnotetext{
${ }^{1}$ Corresponding author:

Email: salsadilla@apps.ipb.ac.id
} 


\section{INTRODUCTION}

Stock market has an important role for the Indonesian economy. One of the economy's pace of development is the availability of funds to finance economic development. Capital market become an option for a company's capital resources. The capital gained from the public offering can be used for the company's business development and expansion. In addition, capital market also can also be an alternative for public investment (Indonesian Stock Exchange Report, 2009). In line with that, Rosul (2002) mentioned that the development of capital market help to attract foreign direct investment and encourage domestic investment. Considering that, stock market performance is highly important to support the economic growth.

Studies focusing about the determinants of stock market stability has been done for the last decades. Domestic and foreign shocks were considered as the main factor affecting the Indonesian stock market (Purnomo and Rider, 2012). Furthermore, a previous research has also studied the impact of news on the stock markets which reflected on the price dynamics (Chan (2003); Vega (2006); Tetlock (2007); Joulin et al. (2008); Birz and Lott (2011); Ormos and Vazsonyi (2011); Jiao, Veiga and Walther (2016)). Moreover, researchers also argued that the stock markets are always affected by major events (Haque and Sarwar (2013), Waheed, Wei, Sarwar and Lv (2018)).

In the meantime, COVID-19 has become a global issue that bought a simultaneous effect all over the world. It was first diagnosed in December 2019 in Wuhan City, China with the first confirmed death case was on January 11th, 2020. For around six months, this virus has been spread in more than 200 countries, having more than 12 million people infected and more than 0.5 million people died in this pandemic. In terms of that, almost all the countries implemented large-scale restriction. This situation bought to a dramatic decline on the overall economic activities. This situation then affects the economic stability including the stock market performance.

The stock market and efficient market's concept explain how the information is transmitted to reach an equilibrium. According to Fama (1970), efficient stock market is considered as a situation in which the available information can be reflected totally on the stock price.
The event study method is widely used in economics and finance empirical studies to identify the impact of unexpected events (Liu et al. 2020). Based on the event study theory, efficient market hypothesis is valid when the impact of unexpected events was reflected on the stock price changes. Hutchison (2003) also argued that event study framework is better suited to the study of intense periods compared to standard time-series studies. Moreover, another advantage of an event study is that the ability to quantify the abnormal impact of 'news' on asset price systematically. Therefore, using event study approach is more relevant to use on this study.

This study contributes to the literature on the Indonesia's sectoral stock market performance. Previous studies are mainly focused on the stock market in general (see e.g. Chandra (2013), Imelda, Siregar and Anggraeni (2014), Suryanto (2015), Gursida and Indrayono (2019)) but not complying to the sectoral impact. Instead of that, recent literatures mostly concern on the unexpected impact of a political or economic event on asset prices. Whereas, none of them focused on the unexpected events like COVID-19. This paper will give empirical findings on the impact of COVID-19 to the sectoral indices. It can also be inferred on which sector were the most affected due to COVID-19 events.

The rest of the paper will be organized as follows: In section 2 will provide the data and research methodology, followed by estimation result on section 3. Summary of the results, the policy implications and suggestions for future research will be provided in section 4.

\section{METHODS}

The data used in this research is the closing price for daily sectoral indices and daily Composite Stock Price Index for Indonesia from 1 December 2017 to 14 April 2020. All data are obtained from Yahoo Finance. Nine companies that represent the largest market capitalization on each sector are included in this research. The lists of companies are presented in Table 1.

The event study approach is used to measure the abnormal return performance in the estimated event period. According to Campbell et al. (1997) steps in the event study approach are as follows: defining the event 
of interest, selection criteria, calculation of normal and abnormal returns, choice of estimation procedure, testing procedure, empirical results and interpretation of results.

The first stage is to analyze abnormal return by determining the event window. The event date used are as follows: (i) the WHO announced the first COVID-19 cases in Wuhan on 31 December 2019; (ii) Wuhan lockdown on 23 January 2020; (iii) the first COVID-19 case in Indonesia on 2 March 2020; (iv) the Indonesian government urged business to suspend operations on 20 March 2020; and (v) President of Indonesia orders large-scale social restriction on 30 March 2020.

An estimation period is used to calculate a stock's Beta value. In this case we have an estimation period of 2 years $[-740,-10]$ from which the alpha (intercept) and beta (slope coefficient) are derived by regressing the market returns to the sectoral stock returns. The test is conducted for 2 event windows, namely $(-5,+5)$ and $(-2 ;+2)$. To calculate the abnormal return, firstly the formulas used are as follows:

$$
\mathrm{R}_{\mathrm{i}, \mathrm{t}}=\left(\mathrm{P}_{\mathrm{i}, \mathrm{t}}-\mathrm{P}_{\mathrm{i}, \mathrm{t}-\mathrm{1}}\right) /\left(\mathrm{P}_{\mathrm{i}, \mathrm{t}-\mathrm{-}}\right)
$$

where: $R_{i, t}$ (actual return of sector indices $i$ on day $\left.t\right) ; P_{i, t}$ (sectoral price indices $\mathrm{i}$ on day $\mathrm{t}$ ); $\mathrm{P}_{\mathrm{i}, \mathrm{t}-1}$ (sectoral price indices $\mathrm{i}$ on day $\mathrm{t}-1$ ).

The expected return is predicted by using simple regression analysis, consistent with an equilibrium model which is the market model procedure widely used as benchmark in event studies. A market model relates stock return to the return of the market portfolio which is the index. The market model is given as:

$$
\mathrm{E}\left(\mathrm{R}_{\mathrm{it}}\right)=\alpha_{\mathrm{i}}+\beta_{\mathrm{i}} \mathrm{Rm}_{\mathrm{t}}+\varepsilon_{\mathrm{it}}
$$

where $E\left(R_{i t}\right)$ is the expectation of stock indices return $\mathrm{i}$ on period $\mathrm{t}$ and $\mathrm{Rm}_{\mathrm{t}}$ is the return of market indices on period t respectively. $\alpha \mathrm{i}$ is the intercept, $\beta_{\mathrm{i}}$ is the systemic risk of stock indices $i$ and $\varepsilon i t$ is the residuals of the market model.

Abnormal return (AR) is defined as the actual ex post return of the asset price over the event window minus the normal return of the asset price over the event window. The abnormal returns are calculated as follows:

$$
\mathrm{AR}_{\mathrm{it}}=\mathrm{R}_{\mathrm{it}}-\mathrm{E}\left(\mathrm{R}_{\mathrm{it}}\right)
$$

where $\mathrm{AR}_{\mathrm{it}}$ is the abnormal return for sectoral indices $i$ on day $t, R_{i t}$ is the actual return of sectoral indices $t, E\left(R_{i t}\right)$ are return expectation of sectoral indices $i$ on day t. The cumulative abnormal return (CAR) for sectoral indices i over the event windows is calculated as follows:

$$
C A R_{i,\left(T_{1}, T_{2}\right)}=\sum_{t=T_{i}}^{T_{2}} A R_{i t}
$$

where $\mathrm{T} 1$ is the first day of the event window and $\mathrm{T} 2$ is the last day of the event window. Lastly a t-test is estimated to measure of some attribute of a sample by using the statistical hypothesis testing. A t-test is a measure of the likelihood which the actual value of the parameter is not zero, The result of t-test then could give a conclusion whether the virus outbreak caused an abnormal return on the sectoral indices.

Table 1. List of companies

\begin{tabular}{lcc}
\hline Sector & Company Name & Code \\
\hline Agriculture & Chandra Asri Petrochemical Ltd. & TPIA \\
Basic Industry and Chemicals & Barito Pasific Ltd. & BRPT \\
Consumer Goods Industry & Unilever Indonesia Ltd. & UNVR \\
Finance & Bank Central Asia Ltd. & BBCA \\
Infrastructure, Utilities, and Transportation & Telekomunikasi Indonesia Ltd. & TLKM \\
Mining & Adaro Energy Ltd. & ADRO \\
Miscellaneous Industry & Astra International Ltd. & ASII \\
Property, Real Estate, and Building Construction & Pakuwon Jati Ltd. & PWON \\
Trade, Service and Investment & Sumber Alfaria Trijaya Ltd. & AMRT \\
\hline
\end{tabular}




\section{RESULTS}

As we know for the last 7 months, the world is made a scene by the COVID-19 event. This event has spread simultaneously and brings a great impact on the economic stability including capital market. On 11 th of March 2020, COVID-19 outbreak has been announced as a pandemic by the World Health Organization. In fact, the first human cases of COVID-19 were identified in Wuhan, China in December 2019. From that day, the pandemic spread rapidly all over the world including in Indonesia. As on 11 July 2020, a total of $12,446,105$ cases are confirmed in more than 227 countries with a 558,683 death cases. So then COVID-19 might become negative sentiment on the capital market, particularly to the stock market.

The goal of this study is to measure the abnormal return in the sectoral indices over the event period. By selecting nine companies from sectors that represent the largest market capitalization, it can be inferred whether there are abnormal returns on the sectoral indices due to COVID-19 or not. This is done by testing the significance of cumulative abnormal return (CAR) using t-statistics on each event. In addition, the sector that brought the greatest respond can also be highlighted.

Two event windows were used to capture the shortterm abnormalities in the stock returns (i.e. $(-2,+2)$ and $(-5,+5))$. Short event windows are chosen because the impact of news is transmitted immediately. This implies that having long event windows might include other external shocks that bought to insignificant impact to the news. The scope of events consists of the event of first confirmed case in Wuhan, the Wuhan lockdown, the first case in Indonesia, to the large-scale social restriction that implemented in Indonesia.

The result of t-test for the impact of COVID-19 on the sectoral indices with different event window are presented in Table 2 and Table 3. These tables give information whether the CAR of stock returns on each sector does statistically significant on the event date or not. Nine models for each event are estimated to see the respond of sectoral indices to COVID-19 outbreak. In general, there are some differences between the 6-days and 11-days event window estimation result. These might due to the length of estimation period that comes to different responses.

Table 2. Impact of COVID-19 on The Sectoral Indices $(-2,+2)$

\begin{tabular}{lccccc}
\hline STOCK & \multicolumn{5}{c}{ CAR $(+2,-2)$} \\
\cline { 2 - 6 } CODE & 31 Des 19 & 23 Jan 20 & 2 Mar 20 & 20 Mar 20 & 30 Mar 20 \\
\hline TPIA & -0.077 & -0.06 & -0.041 & 0.045 & -0.194 \\
BRPT & $(-1.896)$ & $(-0.601)$ & $(-0.797)$ & -0.371 & $(-2.424)^{*}$ \\
& -0.142 & 0.009 & -0.018 & -0.121 & 0.411 \\
UNVR & $-1.959)$ & -0.185 & $(-0.282)$ & $(-1.554)$ & $(2.537)^{*}$ \\
& 0.011 & 0.015 & 0.027 & 0.004 & 0.12 \\
BBCA & -0.353 & -0.362 & -0.543 & -0.034 & -0.812 \\
& 0.012 & 0.011 & 0.005 & 0.085 & 0.102 \\
TLKM & -1.1 & -0.533 & -0.156 & $(-0.645)$ & -1.083 \\
& 0.003 & 0.032 & 0.098 & 0.048 & 0.011 \\
ADRO & -0.134 & -1.252 & $(5.149)^{* *}$ & -0.606 & -0.151 \\
& -0.022 & -0.079 & -0.027 & 0.333 & 0.023 \\
ASII & $(-0.468)$ & $(-1.697)$ & $(-0.506)$ & -2.253 & -0.262 \\
& -0.006 & -0.017 & -0.002 & -0.11 & -0.005 \\
PWON & $(-0.251)$ & $(-0.894)$ & $-0.012)$ & $(-1.874)$ & $(-0.051)$ \\
& -0.04 & -0.044 & 0.028 & -0.072 & -0.02 \\
AMRT & $(-1.632)$ & $(-1.217)$ & -1.076 & $(-1.165)$ & $(-0.256)$ \\
& 0.005 & 0.007 & -0.025 & -0.071 & 0.133 \\
& -0.053 & -0.603 & $(-0.328)$ & $(-1.234)$ & -0.856 \\
\hline
\end{tabular}

Notes: The number in brackets represents the t-test $* *,{ }^{*}$ represents significance at $5 \%$ and $10 \%$.

The critical value are $3.182,2.353$ for $5 \%$ and $10 \%$ respectively 
Table 3. Impact of COVID-19 on The Sectoral Indices $(-5,+5)$

\begin{tabular}{cccccc}
\hline \multirow{2}{*}{ STOCK } & \multicolumn{5}{c}{ CAR $(-5,+5)$} \\
\cline { 2 - 6 } CODE & 31 Des 19 & 23 Jan 20 & 2 Mar 20 & 20 Mar 20 & 30 Mar 20 \\
\hline TPIA & -0.068 & -0.049 & -0.129 & -0.205 & 0.162 \\
BRPT & $(-0.832)$ & $(-0.492)$ & $(-0.981)$ & $(-1.097)$ & -0.62 \\
& -0.148 & -0.055 & -0.214 & -0.055 & 0.602 \\
UNVR & $(-1.629)$ & $(-0.714)$ & $(-2.199)^{*}$ & $(-0.27)$ & $(2.132)^{*}$ \\
& 0.031 & 0.011 & 0.08 & 0.015 & 0.118 \\
BBCA & -0.825 & -0.285 & -1.233 & -0.099 & $(0.677)$ \\
& 0.009 & 0.006 & -0.035 & 0.075 & 0.085 \\
TLKM & -0.636 & -0.271 & $(-0.907)$ & -0.618 & $(0.784)$ \\
& 0.012 & 0.042 & 0.119 & 0.087 & 0.047 \\
ADRO & -0.33 & -1.179 & $(3.062)^{* *}$ & -0.912 & $(0.455)$ \\
& -0.026 & -0.084 & -0.079 & 0.263 & 0.389 \\
ASII & $(-0.3)$ & $(-1.284)$ & $(-1.1)$ & -1.211 & $(2.053)^{*}$ \\
& 0.002 & -0.037 & -0.036 & -0.117 & -0.137 \\
PWON & -0.047 & $(-1.032)$ & $(-0.358)$ & $(-1.083)$ & $(-1.193)$ \\
& -0.013 & -0.045 & 0.053 & -0.11 & 0.104 \\
AMRT & $(-0.197)$ & $(-1.009)$ & -0.678 & $(-0.81)$ & $(0.553)$ \\
& -0.006 & -0.024 & 0.034 & -0.017 & 0.053 \\
& $(-0.056)$ & $(-0.53)$ & -0.378 & $(-0.145)$ & $(0.296)$ \\
\hline
\end{tabular}

Notes: The number in brackets represents the t-test **, ${ }^{*}$ represents significance at $5 \%$ and $10 \%$.

The critical value are $3.182,2.353$ for $5 \%$ and $10 \%$ respectively

From the findings, both on the 6-days and 11-days event window, there were found abnormal returns in the Basic Industry and Chemicals sector (Barito Pasific Ltd.), and Infrastructure, Utilities and Transportation sector (Telekomunikasi Indonesia Ltd.). However, there were abnormal returns on the Agricultural sector (Chandra Asri Petro Chemical Ltd.) only at the 6-days event window, but not at the 11-days event window. This means that there was only a sudden effect in the Agricultural sector due to COVID-19. In opposite, for Mining sector (Adaro Energy Ltd.), abnormal returns were only found at the 11-days event window which indicate the need of longer period to be affected by COVID-19. In general, sectors that were firstly affected by COVID-19 are categorized as primary sectors.

For the other sectors such as Consumer Goods Industry sector, Finance sector, Miscellaneous Industry sector, Property, Real Estate and Building Construction sector, and Trade, Service and Investment sector, no abnormal returns were found on the estimation period. However, there might be possibilities having different results by using different time period. As an example, COVID-19 effect on the Consumer Goods Industry sector might be exist after the large-scale social restriction are implemented. In addition, for those sectors who has low level of liquidity like Property, Real Estate and Building
Construction sector, the respond to COVID-19 might takes to a longer period. By using event study, different event dates might give different results which means that it takes time for other sectors to be affected by the impact of COVID-19.

\section{Managerial Implications}

Considering the important role of stock market for Indonesian economy, the performance of Indonesia's sectoral stock market has become a crucial issue for the past decades. As consequences, the determinants of stock market stability must be identified in order to mitigate its risk. This research has contributed to the literature that Indonesia's sectoral stock market was affected by unexpected events such as COVID-19. So then, not only political or economic events, but also outbreak issue can influence the stock market stability. Furthermore, there are few sectors that found to have abnormal returns in the period between 2nd of March 2020 (first confirmed case in Indonesia) until 30th of March 2020 (large scale social restriction in Indonesia) with both 6 days and 11 days event windows. They are Basic Industry and Chemicals sector, Utilities and Transportation sector, Agricultural sector, and Mining sector. These findings give information to the investors, companies and policy maker to anticipate and mitigate 
the possibilities of risk in the sectoral stock market. Furthermore, the results also can contribute to the determinants of stock market stability that comes up to the economic stability.

\section{CONCLUSIONS AND RECOMMENDATIONS}

\section{Conclusions}

This paper examines the impact of COVID-19 on the Indonesia's sectoral stock market performance that represented by companies from sectors with the biggest market capitalization in Indonesia. To identify the abnormal returns due to the outbreak, the event dates have included the chronological effect from the first confirmed case in Wuhan until the large-scale restriction that has implemented in Indonesia.

The finding showed that COVID-19 events does appear to be related significantly to the abnormal returns on the Agricultural sector, Basic Industry and Chemicals sector, Infrastructure, Utilities and Transportation sector, and also Mining sectors. In detail, there was only a sudden effect of COVID-19 in the Agricultural sectors. However, Mining sector needs a longer period to be affected by COVID-19. And for the other sectors, the abnormal returns were not found during the event period.

\section{Recommendations}

The next interesting research would be widening the estimation period. This is important because different event windows might give different results. In addition, by including other countries to the study will bring a more comprehensive result.

\section{REFERENCES}

Birz G, Lott JRJ. 2011. The effect of macroeconomic news on stock returns: new evidence from newspaper coverage. Journal of Banking \& Finance 35: 2791-2800. https://doi. org/10.1016/j.jbankfin.2011.03.006.

Campbell JY, Lo AW, Mc Kinlay AC. 1997. The Econometrics of Financial Markets. New Jersey: Princeton University Press. https://doi. org/10.1515/9781400830213.

Chan WS. 2003. Stock price reaction to news and no- news: drift and reversal after headlines. Journal of Financial Economics 70: 223-260. https:// doi.org/10.1016/S0304-405X(03)00146-6.

Chandra T. 2013. The impact of fuel price increase on stock price in Indonesia stock exchange. Journal of Economics, Business and Accountancy 16(3). https://doi.org/10.14414/jebav.v16i3.219.

Fama EF. 1970. Efficient capital markets: a review of theory and empirical work. The Journal of Finance 25(2): 383-417. https://doi. org/10.2307/2325486.

Gursida H, Indrayono Y. 2019. Understanding capital market responses to government economic Policy announcements: an event study on Indonesia's economic policy package. Management Science Letters 9(2019): 1887-1900. https://doi. org/10.5267/j.msl.2019.6.004.

Haque A, Sarwar S. 2013. Effect of fundamental and stock market variables on equity return in Pakistan. Science International 25(4): 981- 987.

Imelda, Siregar H, Anggraeni L. 2014. Abnormal returns and trading volume in the Indonesian stock market in relation to the Presidential Elections in 2004, 2009, and 2014. International Journal of Administrative Science and Organization 21(2):61-76.https://doi.org/10.20476/jbb. v21i2.4319.

Jiao P, Veiga A, Walther A. 2016. Social Media, News Media, and the Stock Market. UK: Research Gate Publication. https://doi.org/10.2139/ ssrn.2755933.

Liu H, Manzoor A, Wang C, Zhang L, Manzoor Z. 2020. The COVID-19 Outbreak and affected countries stock markets response. International Journal of Environmental Research and Public Health 17(8):1-19. https://doi.org/10.3390/ ijerph17082800.

Ormos M, Vazsonyi M. 2011. Impacts of Public News on Stock Market Prices: Evidence from S\&P500. Interdisciplinary Journal of Research in Business 1(2): 1-17.

Purnomo B, Rider MW. 2012. Domestic and Foreign Shocks and the Indonesian Stock Market: Time Series Evidence. Yogyakarta: Gajahmada University Press.

Rosul M. 2002. The Capital Market in Indonesia's Economy: Development and Prospects. Tokyo: AT10 Research Conference, Nomura Foundation Japan.

Suryanto. 2015. Analysis of abnormal return before and after the announcement of investment grade 
Indonesia. International Journal of Business and Management Review 3(1): 11-23.

Tetlock PC. 2007. Giving content to investor sentiment: The role of media in the stock market. Journal of Finance LXII: 1139-1168. https://doi. org/10.1111/j.1540-6261.2007.01232.x.

Vega C. 2006. Stock price reaction to public and private information. Journal of Financial Economics 82: 103-133. https://doi.org/10.1016/j. jifineco.2005.07.011.

Waheed R, Wei C, Sarwar S, Lv Y. 2018. Impact of oil prices on firm stock return: industry wise analysis. Empirical Economics 55(2): 765- 780. https://doi.org/10.1007/s00181-017-1296-4. 